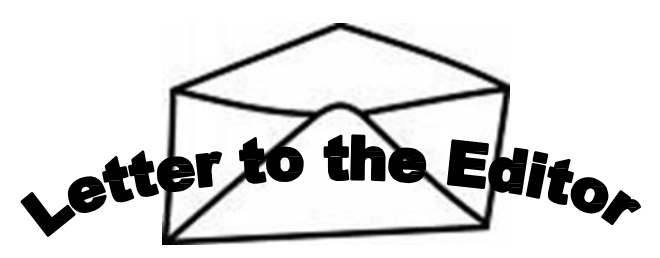

\title{
Erratum: Knowledge and Attitudes of Physicians in Kansas Regarding Domestic Minor Sex Trafficking
}

An error appeared in the November 2012 article, Knowledge and Attitudes of Physicians in Kansas Regarding Domestic Minor Sex Trafficking. ${ }^{1}$ On page 152, reference number 11 was listed incorrectly as:

Hovath M. Human trafficking and the commercial sexual exploitation of children and youth in Kansas. Huffington Post. August 2, 2010. http://www.huffingtonpost.com/markhorvath/human-trafficking-and-the_b_664567.html. Accessed January 15, 2011.

The correct reference is:

Countryman-Roswurm K. Kansas human trafficking and the commercial sexual exploitation of children and youth. In: Hovath M. Human trafficking and the commercial sexual exploitation of children and youth in Kansas. Huffington Post. August 2, 2010. http://www.huffingtonpost.com/mark-horvath/human-trafficking-and-the_b_664567.html. Accessed January 15, 2011.

We regret the error.

Sincerely,

Gina M. Berg, Ph.D.

\section{Reference}

${ }^{1}$ Reinhard A, Whitacre I, Hervey AM, Berg GM. Knowledge and attitudes of physicians in Kansas regarding domestic minor sex trafficking. KS J Med 2012; 5(4):142-153. 